\title{
Aseptic Neutrophilic Meningitis With Hypoglycorrhachia Following a Single Ocrelizumab Infusion
} Steven Cicero, BS, * Eero Rissanen, MD, PhD, ${ }^{*}$ Kelsey Carter, MSN, RN, Hung Nguyen, MD, Raymond Petit, MD,
Todd B. Ellerin, MD, Ranbir Dhillon, MD, and Tarun Singhal, MD

Neurol Neuroimmunol Neuroinflamm 2021;8:e1025. doi:10.1212/NXI.0000000000001025

An increasing number of disease-modifying therapies (DMTs) are being approved for treatment of multiple sclerosis (MS). Ocrelizumab is a humanized B cell-depleting monoclonal antibody, recently approved for relapsing and primary progressive MS. ${ }^{1}$ Here, we present a patient with MS who developed an acute aseptic neutrophilic meningitis following ocrelizumab initiation.

\section{Case Presentation}

A 54-year-old woman diagnosed with relapsing MS 5 years earlier was on fingolimod, but it was decided to switch to ocrelizumab because of a new cervical spinal cord lesion and clinical worsening. Before initiating ocrelizumab, her timed 25-foot walk (T25-FW) was 11.4 seconds, and the Expanded Disability Status Scale (EDSS) score was 6.5, the primary symptoms being left-sided weakness and left-hand tremors. Routine safety laboratory results were normal (table). She received the first $300 \mathrm{mg}$ ocrelizumab infusion without any immediate side effects.

However, 10 days after the first ocrelizumab dose, the patient developed a severe, acute-onset frontal headache with episodic confusion, photophobia, and nonsensical slurred speech, which had lasted for 1 day on presentation to the hospital. On admission, body temperature was $99.4 \mathrm{~F}$, and the patient was hemodynamically stable without meningismus. Blood tests showed neutrophilic leukocytosis and slight absolute bandemia (table). A head CT, chest X-ray, and urinalysis were normal. Lumbar puncture (LP) revealed predominantly neutrophilic pleocytosis (9,789 white blood cells [WBCs], $88 \%$ polymorphonuclear cells), elevated protein $(399.3 \mathrm{mg} / \mathrm{dL})$, and low glucose $(30$ $\mathrm{mg} / \mathrm{dL}$ ) in the CSF (table). A brain MRI showed multiple hemispheric white matter, brainstem, and cerebellar MS lesions without contrast enhancement that were unchanged compared with a scan 2.5 months prior. Empiric IV antimicrobial treatment with ampicillin, ceftriaxone, vancomycin, and acyclovir was initiated. CSF HSV, VZV, and JCV PCRs returned negative. The patient began to recover within 24-48 hours following admission. A repeat LP performed 3 days following the initial LP showed improved findings ( $255 \mathrm{WBCs}$, total protein $70 \mathrm{mg} / \mathrm{dL}$, and glucose $46 \mathrm{mg} / \mathrm{dL}$; table). Blood and CSF bacterial and fungal cultures, cryptococcal antigen, and Lyme tests returned negative, and the antimicrobial treatments were terminated 10 days following admission. The patient improved with only mild headache at discharge 11 days following admission. The tetrad of profound neutrophilic meningitis with low glucose, rapid clinical recovery, completely negative infectious disease workup, and recently initiated new medication (ocrelizumab) suggested that the patient had a probable drug induced aseptic meningitis (DIAM).

At the neurology outpatient control visit 23 days following discharge, her EDSS score and T25FW were unchanged. Due to the risk of recurring DIAM, ${ }^{2}$ it was decided not to rechallenge the
Correspondence

Dr. Singhal

tsinghal@bwh.harvard.edu

*These authors contributed equally to this work as co-first authors.

From the Brigham Multiple Sclerosis Center (S.C., E.R., K.C., T.S.), Ann Romney Center for Neurologic Diseases, Department of Neurology, Brigham and Women's Hospital, Harvard Medical School, Boston, MA; Sturdy Memorial Hospital (H.N., R.P., R.D., T.S.), Attleboro, MA; and Division of Infectious Disease (T.B.E.), Department of Medicine, Brigham and Women's Hospital, Harvard Medical School, Boston, MA.

Go to Neurology.org/NN for full disclosures. Funding information is provided at the end of the article.

The Article Processing Charge was funded by the authors.

This is an open access article distributed under the terms of the Creative Commons Attribution-NonCommercial-NoDerivatives License 4.0 (CC BY-NC-ND), which permits downloading and sharing the work provided it is properly cited. The work cannot be changed in any way or used commercially without permission from the journal. 
Table Essential CSF and Peripheral Blood Laboratory Results Obtained Before the Initiation of Ocrelizumab, on Admission and After 3-Day Inpatient Stay

\begin{tabular}{|c|c|c|c|c|}
\hline Test name (normal range and unit) & On fingolimod ${ }^{a}$ & Pre-ocrelizumab & Admission (day 0 ) & Follow-up (+3 d) \\
\hline CSF WBC count $\left(<6 / \mathrm{mm}^{3}\right)$ & N/A & $\mathrm{N} / \mathrm{A}$ & $9,789^{c}$ & $255^{d}$ \\
\hline $\begin{array}{l}\text { CSF WBC differential count } \\
\text { Polymorphonuclear leukocytes, \% } \\
\text { Lymphocytes, \% } \\
\text { Monocytes, \% }\end{array}$ & N/A & $N / A$ & $\begin{array}{l}88 \% \\
2 \% \\
10 \%\end{array}$ & $\begin{array}{l}32 \% \\
11 \% \\
57 \%\end{array}$ \\
\hline CSF glucose $(40-80 \mathrm{mg} / \mathrm{dL})$ & N/A & $N / A$ & 30 & 46 \\
\hline CSF total protein $(15-45 \mathrm{mg} / \mathrm{dL})$ & N/A & $N / A$ & 399.3 & 70 \\
\hline Blood WBC count $\left(3.5-10.5 \times 10^{3} / \mu \mathrm{L}\right)$ & 2.4 & 4.5 & 18.7 & 10.6 \\
\hline $\begin{array}{l}\text { Blood WBC differential } \\
\text { Immature granulocytes }(0.001-0.429 \%) \\
\text { Neutrophils }(45-90 \%) \\
\text { Lymphocytes }(16-57 \%) \\
\text { Monocytes }(3-10 \%) \\
\text { Eosinophils }(0-5 \%) \\
\text { Basophils }(0-2 \%)\end{array}$ & $\begin{array}{l}0 \% \\
69 \% \\
18 \% \\
13 \% \\
0 \% \\
0 \%\end{array}$ & $\begin{array}{l}0.2 \% \\
71.2 \% \\
18.4 \% \\
9.1 \% \\
0.9 \% \\
0.2 \%\end{array}$ & $\begin{array}{l}0.3 \% \\
84.8 \% \\
5.5 \% \\
9.3 \% \\
0 \% \\
0.1\end{array}$ & $\begin{array}{l}0.2 \% \\
82.2 \% \\
10.0 \% \\
7.3 \% \\
0.2 \% \\
0.1 \%\end{array}$ \\
\hline Absolute lymphocyte count & 430 & 830 & 1,030 & 1,060 \\
\hline Blood CD19 cells (7.0-27.0\% of lymphs) & $4 \%$ & $N / A$ & $N / A$ & $N / A^{e}$ \\
\hline Blood glucose $(70-110 \mathrm{mg} / \mathrm{dL})$ & 91 & $N / A$ & 137 & $\mathrm{~N} / \mathrm{A}$ \\
\hline Blood total protein $(6.4-8.2 \mathrm{~g} / \mathrm{dL})$ & 6.6 & $N / A$ & 6.3 & N/A \\
\hline
\end{tabular}

Abbreviations: RBC = red blood cell; $\mathrm{WBC}=$ white blood cell.

a One week before discontinuing fingolimod.

${ }^{\mathrm{b}}$ Five weeks after discontinuation of fingolimod. Ocrelizumab was administered approximately 6 weeks after the last fingolimod dose.

${ }^{\circ} 64-73$ and ${ }^{d} 57-9$ red blood cells in the CSF sample, compatible with slight peripheral blood artifact.

e 1 month after admission, the blood CD19 cell percentage was 0\%. At the same time point, immunoglobulin lgG was 598 (normal range $700-1,600) \mathrm{mg} / \mathrm{dL}$ and IgM 41 (normal range 40-230) mg/dL.

patient with ocrelizumab. Rituximab was considered as an alternative DMT, but in the absence of MS disease activity at that time, it was agreed to hold off on initiating a new DMT, particularly in accordance with the patient's wishes. There was no evidence of clinical or radiologic disease activity, and the patient remained off DMTs during 2-year follow-up.

\section{Discussion}

The clinical diagnosis was determined to be probable DIAM following ocrelizumab treatment. The evidence supporting clinical diagnosis of DIAM included a CSF profile consistent with DIAM, ${ }^{2-4}$ negative microbial cultures obtained before initiation of any antimicrobial treatment, rapid resolution of symptoms, and recent initiation of ocrelizumab.

Although the findings of neutrophilic leukocytosis in CSF and peripheral blood along with bandemia, normal-to-low CSF glucose, and elevated CSF proteins are commonly seen in acute bacterial meningitis, these findings have also been reported in DIAM. ${ }^{2-4}$ Usually, the symptom regression in DIAM occurs within 1-5 days ${ }^{3}$ However, the time range from the intake of the drug to the onset of the symptoms in DIAM can vary from less than an hour to several months, longer delays being observed for biologics. ${ }^{2,3}$ Ocrelizumab has an estimated terminal half-life of 26 days, ${ }^{5}$ which could account for longer delay from administration to symptom onset when compared with the classical DIAM-causing drugs, NSAIDs. ${ }^{2}$

Of interest, rituximab, a chimeric monoclonal anti-CD20 antibody, ${ }^{1}$ has been reported as a causative agent for DIAM in 3 individual cases. ${ }^{6}$ Two lymphocytic meningitis cases associated with ocrelizumab, both after 1-year treatment and occurring not until after 6 months from the latest ocrelizumab infusion, have been reported before. ${ }^{7}$ Our case is unique because of ocrelizumab associated neutrophilic DIAM and hypoglycorrhachia, which developed shortly after a single drug dose.

The pathogenic mechanism of anti-CD20 antibody associated DIAM is not known. Generally, DIAM mechanisms are incompletely understood, albeit hypersensitivity is considered the most plausible mechanism. ${ }^{3}$ Very rare serious adverse events such as DIAM may remain undetected in randomized clinical trials despite large sample sizes.

In conclusion, DIAM, which can mimic acute bacterial meningitis, should be recognized as a potential adverse event of ocrelizumab in patients with MS.

\section{Study Funding}

No targeted funding reported. 


\section{Disclosure}

S. Cicero reports no disclosures relevant to the manuscript. E. Rissanen has received a Sigrid Juselius Fellowship Grant. K. Carter, H. Nguyen, R. Petit, and T.B. Ellerin report no disclosures relevant to the manuscript. $\mathrm{R}$. Dhillon has received speaker honoraria from Biogen, Bristol-Myers Squibb, and Sanofi. T. Singhal has received research grant support from Sanofi-Genzyme and Novartis Pharmaceuticals. Go to Neurology.org/NN for full disclosures.

\section{Publication History}

Received by Neurology: Neuroimmunology \& Neuroinflammation January 25, 2021. Accepted in final form April 26, 2021.

\section{Appendix Authors}

\begin{tabular}{|c|c|c|}
\hline Name & Location & Contribution \\
\hline $\begin{array}{l}\text { Steven } \\
\text { Cicero, BS }\end{array}$ & $\begin{array}{l}\text { Brigham Multiple Sclerosis } \\
\text { Center, Ann Romney Center } \\
\text { for Neurologic Diseases, } \\
\text { Department of Neurology, } \\
\text { Brigham and Women's } \\
\text { Hospital, Harvard Medical } \\
\text { School, Boston, MA }\end{array}$ & $\begin{array}{l}\text { Drafting/revision of the } \\
\text { manuscript for content, } \\
\text { including medical writing for } \\
\text { content; major role in the } \\
\text { acquisition of data; analysis or } \\
\text { interpretation of data }\end{array}$ \\
\hline $\begin{array}{l}\text { Eero } \\
\text { Rissanen, } \\
\text { MD, PhD }\end{array}$ & $\begin{array}{l}\text { Brigham Multiple Sclerosis } \\
\text { Center, Ann Romney Center for } \\
\text { Neurologic Diseases, } \\
\text { Department of Neurology, } \\
\text { Brigham and Women's } \\
\text { Hospital, Harvard Medical } \\
\text { School, Boston, MA }\end{array}$ & $\begin{array}{l}\text { Drafting/revision of the } \\
\text { manuscript for content, } \\
\text { including medical writing for } \\
\text { content; major role in the } \\
\text { acquisition of data; analysis or } \\
\text { interpretation of data }\end{array}$ \\
\hline $\begin{array}{l}\text { Kelsey } \\
\text { Carter, } \\
\text { MSN, RN }\end{array}$ & $\begin{array}{l}\text { Brigham Multiple Sclerosis } \\
\text { Center, Ann Romney Center for } \\
\text { Neurologic Diseases, } \\
\text { Department of Neurology, } \\
\text { Brigham and Women's } \\
\text { Hospital, Harvard Medical } \\
\text { School, Boston, MA }\end{array}$ & $\begin{array}{l}\text { Drafting/revision of the } \\
\text { manuscript for content, } \\
\text { including medical writing for } \\
\text { content; major role in the } \\
\text { acquisition of data }\end{array}$ \\
\hline $\begin{array}{l}\text { Hung } \\
\text { Nguyen, } \\
\text { MD }\end{array}$ & $\begin{array}{l}\text { Sturdy Memorial Hospital, } \\
\text { Attleboro, MA }\end{array}$ & $\begin{array}{l}\text { Drafting/revision of the } \\
\text { manuscript for content, } \\
\text { including medical writing for } \\
\text { content; major role in the } \\
\text { acquisition of data }\end{array}$ \\
\hline
\end{tabular}

Appendix (continued)

\begin{tabular}{|c|c|c|}
\hline Name & Location & Contribution \\
\hline $\begin{array}{l}\text { Raymond } \\
\text { Petit, MD }\end{array}$ & $\begin{array}{l}\text { Sturdy Memorial Hospital, } \\
\text { Attleboro, MA }\end{array}$ & $\begin{array}{l}\text { Drafting/revision of the } \\
\text { manuscript for content, } \\
\text { including medical writing for } \\
\text { content; major role in the } \\
\text { acquisition of data }\end{array}$ \\
\hline $\begin{array}{l}\text { Todd B } \\
\text { Ellerin, } \\
\text { MD }\end{array}$ & $\begin{array}{l}\text { Division of Infectious Disease, } \\
\text { Department of Medicine, } \\
\text { Brigham and Women's } \\
\text { Hospital, Harvard Medical } \\
\text { School, Boston, MA }\end{array}$ & $\begin{array}{l}\text { Drafting/revision of the } \\
\text { manuscript for content, } \\
\text { including medical } \\
\text { writing for content; analysis } \\
\text { or interpretation of } \\
\text { data }\end{array}$ \\
\hline $\begin{array}{l}\text { Ranbir } \\
\text { Dhillon, } \\
\text { MD }\end{array}$ & $\begin{array}{l}\text { Sturdy Memorial Hospital, } \\
\text { Attleboro, MA }\end{array}$ & $\begin{array}{l}\text { Drafting/revision of the } \\
\text { manuscript for content, } \\
\text { including medical writing for } \\
\text { content; major role in the } \\
\text { acquisition of data }\end{array}$ \\
\hline $\begin{array}{l}\text { Tarun } \\
\text { Singhal, } \\
\text { MD }\end{array}$ & $\begin{array}{l}\text { Brigham Multiple Sclerosis } \\
\text { Center, Ann Romney } \\
\text { Center for Neurologic } \\
\text { Diseases, Department of } \\
\text { Neurology, Brigham and } \\
\text { Women's Hospital, } \\
\text { Harvard Medical School, } \\
\text { Boston, MA; Sturdy } \\
\text { Memorial Hospital, Attleboro, } \\
\text { MA }\end{array}$ & $\begin{array}{l}\text { Drafting/revision of the } \\
\text { manuscript for content, } \\
\text { including medical writing for } \\
\text { content; major role in the } \\
\text { acquisition of data; study } \\
\text { concept or design; analysis or } \\
\text { interpretation of data }\end{array}$ \\
\hline
\end{tabular}

\section{References}

1. Myhr KM, Torkildsen O, Lossius A, Bo L, Holmoy T. B cell depletion in the treatment of multiple sclerosis. Expert Opin Biol Ther. 2019;19(3):261-271.

2. Moris G, Garcia-Monco JC. The challenge of drug-induced aseptic meningitis. Arch Intern Med. 1999;159(11):1185-1194.

3. Moris G, Garcia-Monco JC. The challenge of drug-induced aseptic meningitis revisited. JAMA Intern Med. 2014;174(9):1511-1512.

4. Redman RCt, Miller JB, Hood M, DeMaio J. Trimethoprim-induced aseptic meningitis in an adolescent male. Pediatrics. 2002;110(pt 2):e26.

5. Gibiansky E, Petry C, Mercier F, et al. Ocrelizumab in relapsing and primary progressive multiple sclerosis: pharmacokinetic and pharmacodynamic analyses of OPERA I, OPERA II and ORATORIO. Br J Clin Pharmacol. 2021;87(6): 2511-2520.

6. Bihan K, Weiss N, Theophile H, Funck-Brentano C, Lebrun-Vignes B. Drug-induced aseptic meningitis: 329 cases from the French pharmacovigilance database analysis. $\mathrm{Br}$ J Clin Pharmacol. 2019;85(11):2540-2546.

7. Theriault M, Solomon AJ. Two cases of meningitis associated with ocrelizumab therapy. Mult Scler Relat Disord. 2020;38:101866. 


\title{
Neurology \\ Neuroimmunology \& Neuroinflammation
}

\author{
Aseptic Neutrophilic Meningitis With Hypoglycorrhachia Following a Single \\ Ocrelizumab Infusion \\ Steven Cicero, Eero Rissanen, Kelsey Carter, et al. \\ Neurol Neuroimmunol Neuroinflamm 2021;8; \\ DOI 10.1212/NXI.0000000000001025
}

This information is current as of July 1, 2021

\begin{abstract}
Updated Information \& Services

References

Subspecialty Collections

Permissions \& Licensing

Reprints

including high resolution figures, can be found at: http://nn.neurology.org/content/8/5/e1025.full.html

This article cites 7 articles, 0 of which you can access for free at: http://nn.neurology.org/content/8/5/e1025.full.html\#\#ref-list-1

This article, along with others on similar topics, appears in the following collection(s):

Multiple sclerosis

http://nn.neurology.org//cgi/collection/multiple_sclerosis its entirety can be found online at:

http://nn.neurology.org/misc/about.xhtml\#permissions

Information about ordering reprints can be found online: http://nn.neurology.org/misc/addir.xhtml\#reprintsus
\end{abstract}

Information about reproducing this article in parts (figures,tables) or in

Neurol Neuroimmunol Neuroinflamm is an official journal of the American Academy of Neurology.

Published since April 2014, it is an open-access, online-only, continuous publication journal. Copyright

Copyright $\odot 2021$ The Author(s). Published by Wolters Kluwer Health, Inc. on behalf of the American Academy of Neurology.. All rights reserved. Online ISSN: 2332-7812.

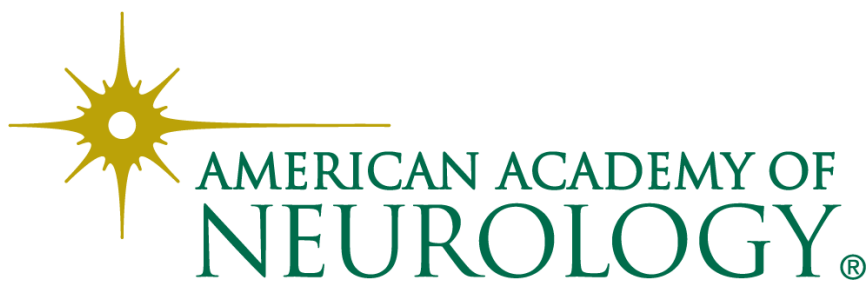

